\title{
Editorial: Learning Lessons from History - or Not?
}

One of Leopold von Ranke's driving forces of his theoretical reflections was to turn historiography into a scientific discipline. This meant expunging the moral dimension from historiographical judgment. In order to arrive at a disinterested view of what really has happened, one should extinguish oneself and one's political and moral aspirations. It is said that Ranke was specifically opposed to Walter Scott's historical novels, which not only failed to stick to the facts, but also appeared to provide moral lessons through the study of the past too. ${ }^{1}$ For example, Southerners in America took Scott's Ivanhoe as a warning that order, even feudal order, is preferable to anarchy. ${ }^{2}$

Perhaps the most common philosophical reason to oppose inferring moral lessons from what has happened in the past is the famous Hume's law, which says that no evaluative, moral or other kind, lessons can be deduced from the factual states of affairs, or from facts. Still, considering the twentieth-century history, it would seem unwise not to try to learn something from history, for example, from the two world wars and the events of the 1930s in Europe. Indeed, witnessing the rise of populism makes many seek comparisons to that decade, often probably too sketchy, and attempt to infer lessons of what to do, and what not, in order to avoid what happened then.

An interesting question is whether human action as a factual component changes the equation between morals and facts at all. It may appear that an act by a human automatically carries some moral significance due to its consequences to others. But even if this was accepted, the relevance of the past for the present and the future hinges upon yet another condition: the past cannot be totally alien to us and to future human beings.

In this issue, several authors consider the relations between morality, responsibility and history. Bennett Gilbert raises a foundational question in the history of ideas: how should ideas be understood? Drawing on material culture studies, his suggestion is that "ideas are relations that persons use to communicate, from which productions and actions flow ... entangled in all human

1 However, Braw argues that this is a misrepresentation. J. D. Braw, "Vision as Revision: Ranke and the Beginning of Modern History", History and Theory 46 (2007), 51.

2 Elizabeth Fox-Genovese and Eugene D. Genovese, The Mind of the Master Class. History and Faith in the Southern Slaveholder's Worldview (Cambridge: Cambridge UP, 2005), 135. 
action and behavior." In this way, he attempts to open a way in which the study of ideas in history is relevant to our moral life and agency. Steven G. Smith asks how a "historically responsible agent" should approach the long-term and inter-generational future. While it may be difficult to agree on "a shared reality of action" on the large historical scale, Smith argues that the notion of historical responsibility of this magnitude provides a sensible normative historical perspective. Christophe Bouton ponders an equally challenging question: can we learn from history? Reinhart Koselleck has suggested that in modern times this is not possible, because the future will always be radically novel, never repeating or reproducing the past. By contrast, Bouton argues that "the topos of history as the 'Guide to Life' is not so much dissolved as rather transformed with modernity."

There are other equally intellectually stimulating articles in this issue. Jonathan Martineau examines Edmund Husserl's conception of time, analysing it specifically in its own social context, which was marked by the modern standardisation of time. His article "seeks to situate Husserl's time in Husserl's times." Chiel van den Akker analyses Arthur Danto's end-of-art thesis, which states that art came to an end in 1964, when Andy Warhol exhibited his Brillo Box. Van den Akker argues that this thesis implies a substantive philosophy of history, which enables recognizing the state of art and its emergence in a particular historical stage. Daniel Fairbrother looks for no less that the soul of historiography and finds it through the philosophies of Aristotle and Ankersmit and in the form of a new theory of holism in historiography. According to it, "historical representations [as wholes] ... represent the ranges of possible actions constituting given historical situations." Finally, Ian Kidd reviews Paul K. Feyerabend's book Philosophy of Nature, which is an unfinished recently discovered manuscript in the Philosophical Archive at the University of Konstanz. Kidd identifies historical contingency as a central although latent theme in the book.

Jouni-Matti Kuukkanen

Editor-in-Chief 